\title{
A decolonial biblical perspective on Jesus inspired by Fanon and Biko
}

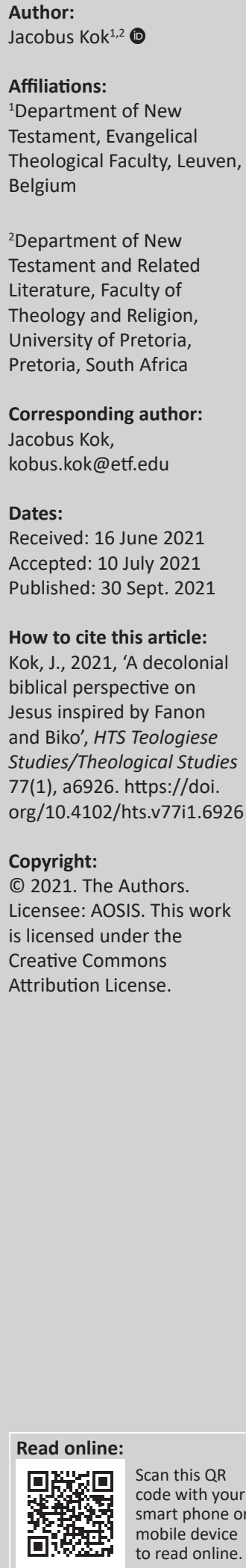

This paper makes an original contribution against the background of relevant postcolonial discourse by means of the methods of postcolonial and social-scientific biblical exegesis from the perspective of critical correlation. The main aim of the paper is to bring into dialogue the insights of Frantz Fanon and Steve Biko, with the latest insights in biblical scholarship on the parables. This study finds that the New Testament can be read critically through the lens of core ideas of Fanon and Biko in critical correlation with understandings of Jesus as reacting against Roman Imperial domination and exploitation. The paper concludes with the suggestion that postcolonial reading scenarios, like the ones we have suggested in this paper, be used in theological training to relate New Testament Exegesis to contemporary challenges around decoloniality in South Africa.

Contribution: The main contribution of this paper is providing key insights into decolonial and postcolonial readings of Jesus as an agent of change reacting against Roman imperial domination and exploitation, addressing the agenda of the special HTS collection of essays focused on the reception of biblical discourse in Africa.

Keywords: decolonial; postcolonial; Biko; Fanon; Parables; Jesus; mustard seed.

\section{Introduction}

In this article, a view of Jesus as an anti-imperial ethical-eschatological prophet from decolonial perspectives is critically discussed. To do so, I will engage with insights from Frantz Fanon and Steve Biko, and critically correlate their insights with new insights in New Testament exegesis from a critical correlation perspective. The structure of the article is as follows. First, the scene is set by an explanation of the need for ongoing critical reflection on post-and-decolonial discourses. This is followed by a discussion of Fanon and Biko. The article then proceeds to engage new insights on parable research which provide us with perspectives to help us to engage a decolonial reading of the Bible.

\section{Setting the scene}

\section{A critical correlation between past and present: The AfricaMuseum in Belgium as case study}

We live amidst the Fourth Industrial Revolution, and a time of superdiversity and super mobility (Kok \& Van den Heuvel 2019:v-vi). In such a revolutionary time, it is inevitable that certain tsunami-like waves of change will burst over the world, as is the case with all major revolutions. By tsunami, we here do not focus on the destruction, but on its power, so strong that it cannot simply be contained. It represents a sea of change and a new landscape in which we ourselves need to navigate. The global experience of the coronavirus (COVID-19) pandemic illustrated our international interconnectivity on the one hand, on the one hand, our international interconnectivity, and on the other, our mutual interdependency.

Our Zeitgeist (or as we say in the Tswana language 'Mowa wa me ngwaga') is characterised by a renewed focus on equality and a sensitivity for how our own ethnocentrism creates boundaries between insiders and outsiders. In a way, this represents a wave of new awareness. Our time is also characterised by an open acknowledgement of how we have been instrumental in the oppression of other people in the past, and how unequal power relations are enacted and transferred systemically. Unfortunately, in contexts like South Africa, we are still not free of subtle legacies of colonialism and should therefore rather, as Mbembe (2021) argues, think of our context as 'postcolony' where we still have much 'de-colonial' work to do to empower our people with

Note: Special Collection: Reception of Biblical Discourse in Africa, sub-edited by Itumeleng Mothoagae (University of South Africa). 
life-giving theology in, for and by Africans. For that, we need new language, new images, new thought, and ongoing reflection (Gordon 2000:x; Mbembe 2021).

Recently, we visited the AfricaMuseum (Koninklijk Museum voor Midden-Afrika) in Tervuren close to Brussels. ${ }^{1}$ This museum was originally built at the end of the 19th century (1897) as a colonial showcase in honour of King Leopold II, displaying his Belgian Congo. Its main aim was to serve as a form of imperial propaganda displaying the power of Belgium and economic opportunities in the Belgian Congo (e.g. coffee, tobacco, cacao). ${ }^{2}$

The museum was closed for several years due to a major renovation project. Not only were the exhibitions rather old and outdated, but more importantly, it did not reflect contemporary decolonial discourses like a decolonial perspective. It re-opened to the public in December 2018, but during the pandemic was again closed to visitors until recently.

Major renovations were done, but more importantly truly significant changes were made to reflect a decolonial perspective meant to serve as an important tool for education of the next generation.

The colonial history is still visible from the colonial images in the naves. These images depict Europeans (Belgians) as the superior 'Parent' civilisation conquering the Congolese who were seen as backward in their thinking, 'primitive' in their ways of life, and objects of exploitation and development. For Africans, these images and the root metaphors they are built on (e.g. parent-child) are radically offensive, especially against the background of a growing awareness of \#BlackLivesMatter and other similar movements or discourses that are part of our Zeitgeist.

Furthermore, as part of the renovation, the museum, in collaboration with the United Nations' Human Rights Council, gave special attention to art in service of decolonisation. One of the leading artists asked to produce new art was Aimé Mpane.

Already in the grand rotunda of the museum the visitor is confronted with two contrasting worldviews. On the one hand, large colonial buildings and remnants of colonial statues depict the superior white European coloniser. On the other hand, the visitor comes face to face with Aimé Mpane's shocking contemporary sculpture Skull of Chief Lusinga, depicting the brutal killing of Lusinga by Belgian officer Emile Storms in 1884.

After much consultation, the Onroerend Erfgoed (Flanders Heritage Agency) decided to not remove the colonial images in the naves, but rather to subdue severely all colonial 1.Viewed 03 May 2021, from https://politicaltheology.com/the-written-out-slaves/. 2.Viewed 03 May 2021, from https://www.africamuseum.be/en/discover/history renovation. propaganda in an effort to accentuate the violence, atrocities and exploitation committed against the Congolese. Across from the large wooden carving of the Skull of Chief Lusinga, we find an even larger wooden statue of an African person representing human dignity, potential and promise.

Aimé Mpane and Belgian artist Jean-Pierre Müller worked together to transform the old colonial images and statues by means of an engagement with the oppressed history the old images embody. Their new project, called RE/STORE, consists of 16 semi-transparent veils placed right in front of each of the colonial statues in the nave. This superposition creates a visual and semantic shock, inevitably inviting dialogue between the past and the present. In their own words, the museum states that this superimposition 'creates.... a semantic shock that allows a new reading of a heavy heritage and challenges its historical and ideological content'. ${ }^{3}$

This form of art is truly inspiring and challenging. It takes a contemporary discourse and paradigm like decolonisation, and reinterprets colonialism and its heritage critically by deconstructing it.

How can biblical scholars contribute to the ongoing discussion of decolonisation? In my opinion, the best place to start is to try and fully understand the lived experience of black people and then to develop an adequate method of critical correlation between the past (biblical) and the present (e.g. post- and decolonial) experiences by asking questions to the ancient biblical texts informed by insights from decolonisation. Thus, as South African biblical scholars, we first need to start with doing theology in and for South Africans, and start with the lived experience of all South Africans - in the case of this article - especially black South Africans.

\section{Understanding white gaze and double consciousness}

In the past, New Testament scholarship reflecting contextually on South Africa was dominated by white males who seldomly fully understood or appreciated the nature of the experiences of a black person with regard to, for example, 'white gaze' and 'double consciousness'. As a result, they neither had a sensitivity to black consciousness nor did they make use of the rich language and metaphors of black consciousness present in literature like that of Fanon and Biko. Furthermore, during apartheid, the works of Biko and others were banned. As a result, white biblical scholars in South Africa were not able to fully engage with these voices. Today, we are in the fortunate position that we may engage with these voices, and aim to reflect on lifegiving theology in and for Africa.

Maluleke (2008:121) quotes Biko as saying: 'In order to achieve real action you must yourself be a living part of 3.Viewed 03 May 2021 , from https://www.africamuseum.be/en/discover/history renovation. 
Africa and of her thought'. To truly transform South Africa, we need to develop a heart for Africa and find ways to associate deeply with the black experience in and for the South African context, and by doing so take a lead in international discourse on the topic (locally relevant, but internationally competitive). When reading Scripture from a critical correlation perspective, we need to decolonise not only our own context and embeddedness, but also our reading of the Bible. We need to read the Bible in a new way, illuminating the way in which Jesus and his earliest followers were challenging the hegemony of their own day with a more person-affirming approach to God and life. For those who do not have a decolonial or black consciousness language, however, the doors of this life-giving theology will be closed until such a consciousness washes one clean in a process of intellectual baptism, inviting one into a whole new world of thought and life-giving possibilities for Africa.

It was the work of Frantz Fanon (1952; 1986 [transl. C. Lam Markmann]), and our own experience of being sojourners and foreign aliens in the heart of Europe, which made us aware of the dynamics involved in black consciousness. It was not in South Africa, but in Europe that we discovered Frantz Fanon's work and that of Steve Biko. These texts and their insights provide one of the critical perspectives and language necessary to deconstruct white male hegemony and in the process to help one with a critical approach to read Scripture in an analytical correlated fashion, taking into consideration the implicit questions and needs of South Africa.

Let us first briefly discuss some important notions in Fanon, who is very rarely engaged with by the white New Testament scholars in South Africa. A discussion of Fanon will sensitise us to understand Biko, and create a critical lens through which one can ask critical questions in the process of engaging the New Testament exegetical task as such.

\section{Frantz Fanon as a black psychiatrist reflecting on black consciousness}

Frantz Fanon was a black psychiatrist born in the French West Indies (Fort-de-France, Martinique) during the interbellum period (1925-1961). He was influenced by Aimé Césaire, Karl Marx, Jean-Paul Sartre and was well-versed in the work of Sigmund Freud (see Mabogo 2008:48).

One of his well-known ideas is double consciousness which he understands as the internal conflict inherent in many black or oppressed people. He notes that the black self is always in some critical dialogue with the self-as-perceived-by-whites. The latter is mostly a negative and devaluing perspective as experienced by the white gaze. Fanon got this idea from William E.B. Du Bois's (1868-1963) monumental work The Souls of Black Folk (Du Bois 1903). ${ }^{4}$ Du Bois himself recounts the experience of having had trouble integrating the two aspects of the self, that of his traditional African identity and that of himself as a person having been educated by a Western

4.See the book of Du Bois (1903), viewed 17 May 2021, from https://www.gutenberg org/files/408/408-h/408-h.htm.
European society. He was very well aware that in this critical dialogue within himself that he had been taught to devalue his black African identity through the eyes of his white education. The latter provided the frame of reference according to which black culture was devalued as backwards and less developed than the Western culture. Consequently, he found himself constantly being critical of himself as he looked at himself through a white racist lens. Being an oppressed person, especially in a minority position in a dominant white world, led to constant feedback to the black person of not being good enough, lacking in some way.

In 1903, Du Bois writes the following vivid account of his experience:

It is a peculiar sensation, this double-consciousness, this sense of always looking at one's self through the eyes of others, of measuring one's soul by the tape of a world that looks on in amused contempt and pity. One ever feels his two-ness, - an American, a Negro; two souls, two thoughts, two unreconciled strivings; two warring ideals in one dark body, whose dogged strength alone keeps it from being torn asunder. ${ }^{5}$

When Du Bois explains his experience of 'a world that looks on in amused contempt and pity', he explains the white gaze.

Many black people might share this experience, but lack the analytical language to explain what they experience. In this regard, Fanon provides one with the critical frame and language to express what one experiences, and also ways in which one could resist oppression. One begins with resisting oppression and domination by understanding what is happening with oneself and realising that sometimes one's greatest enemy is oneself, that is, if one is colonised in one's own mind. Said differently, decolonial resistance starts with consciousness of self and language and metaphors to express such consciousness. Fanon points out that many black people in his day would in their own minds accept the superiority of white Western European culture and would emulate that culture by the way they speak, dress, carry themselves, eat, etc. In this sense, they strive towards being white. However, they find that in the white gaze, they are always not good enough, and never will be. He mentions examples of how white men would change the way they talk if they encounter a black man. They would change their vocabulary, even their accent to emulate the way black people speak and would use slang. For Fanon, it is important to see the problem here, namely that white people, by implication, position the black person in an inferior and weaker position. In the case of Fanon, being a highly educated person, this is rather striking as he is being put in a devalued position based on his skin. He finds that white people keep on reproducing the system's hierarchy and oppression. In turn, this becomes a mirror projecting back an image in which the black person sees himself or herself through the devaluing eyes of white racist schemas. These schemas are socialised and embedded within the fabric of society and seen as just the way things are. One example is the experience of a black person watching a movie 5.Du Bois (1903:ad loc) in chapter one of his book, viewed 17 May 2021, from https://www.gutenberg.org/files/408/408-h/408-h.htm. 
or an advertisement during the time in which Fanon writes (1950s-1961), and how the identity of the black man is simply stereotyped and framed within the confines of a pre-existing racist and devaluating schema, reducing the black person to someone less sophisticated, inferior, and even an unwanted outsider. For Fanon, true emancipation implies that one resists these kind of confining devalued stereotyped misrepresentations. By allowing it, one participates in the sustaining of these discourses. For that reason, Fanon feels that one must actively resist this by not allowing it to be reproduced in oneself, and also not to allow such discrimination in public discourse.

The notion of double consciousness and the white gaze is indeed something that still rings true more than a century after Du Bois and half a century after Fanon expressed it. Many have tried to relate these ideas to their experience in the African diaspora (Campt 2014). But perhaps the experiences of black South Africans are different in the sense that black people in Germany (e.g. Campt), who now reflect on their embodied experience of blackness, do so long after the processes of societal inclusion after World War II and the atrocities of Nazism were addressed. Perhaps such people are also not fully aware of the implication of the duality of a black cultural experience vis à vis a European cultural experience as is the case in South Africa. For that reason, it would perhaps be more fruitful for South African scholars to reflect upon their experience in South Africa, and do so by engaging with leading figures like Steve Biko, who have shaped South African black consciousness.

\section{Stephen Biko as prophetic voice}

Banthu Stephen Biko (1946-1977), was a South African antiapartheid activist. Born in a relatively humble Xhosa family, he excelled academically and initially studied medicine, a rarity among South African black people at the time (1960s). He was unable to complete his medical studies because of his political involvement and later studied law.

Disillusioned by the paternalistic domination of white liberal students in the National Union of South African Students (NUSAS), he started the black-only South African Student's Organization (SASO) in 1968, and remained a prominent member alongside others like Barney Pityana. His prominence in these groups, and especially his writings, would make him a prominent target of the state security police at whose hands he was eventually murdered in $1977 .{ }^{6}$

Biko was strongly influenced by the works of Frantz Fanon. Already during his high school years in a Catholic boarding school (St. Francis College in Mariannhill [Natal]), he was exposed to literature which would lead him to develop an appreciation for the Algerian and Kenyan struggles of independence. SASO was driven by a black consciousness ideology which wanted to free the black person from all 6.Viewed 17 May 2021 , from https://www.sahistory.org.za/article/formation-sasoand-black-peoples-convention. systems and thoughts that make of him or her foreigner in their own country, and by empowering blacks with dignity. It was in this context that Biko coined the expression 'Black is Beautiful'.

Taking the short discussion of Fanon into consideration, one can see the same line of thought in Biko:

Black Consciousness directs itself to the black man and to his situation, and the black man is subjected to two forces in this country. He is first of all oppressed by an external world through institutionalised machinery and through laws that restrict him from doing certain things, through heavy work conditions, through poor pay, through difficult living conditions, through poor education, these are all external to him. Secondly, and this we regard as the most important, the black man in himself has developed a certain state of alienation, he rejects himself precisely because he attaches the meaning white to all that is good, in other words he equates good with white. This arises out of his living and it arises out of his development from childhood. (Steve Biko as quoted in Woods [1978] 1991:124)

One of the prominent discourses in the thinking of Biko is that learned inferiority, which Fanon also speaks of, should be deliberately unlearned. In his chapter 'We Blacks', he uses the metaphor of an empty shell and says that black people have become 'a shadow of man, completely defeated, drowning in his own misery, a slave, an ox bearing the yoke of oppression with sheepish timidity' (Biko [1978] 1987:29).

For Biko, one has to face this brutal and honest truth before one can commence with any programme to transform this negative contrast experience. To recover what was lost, one first has to describe the loss. Then only can one 'pump back life into this empty shell; to infuse him with pride and dignity' (Biko [1978] 1987:29). Thus, one first has to start with a critical 'inward-looking process'. Such an inward process of reaffirmation of one's own value should find shape externally. In the context of the 1970s, Biko expresses the problem associated with history that the black child is confronted within which he learns to hate his own heritage. Biko already clearly sees that the only way to empower blacks was to have a black consciousness directed also at the past in which (positive) history is retold in a way that honours and does justice to African heroes and African culture. Biko ([1978] 1987:29) mentions this so beautifully: 'A people without a positive history is like a vehicle without an engine', - and shall we add - an empty shell. The challenge is to help black people to see the immense value in their own values and history.

These insights also have implications for Theology. Biko argues that in absolute destitution black people might give up and shout 'Thy will be done'. But then he says, No! 'If the white God has been doing the talking all along, at some stage the black God will raise his voice and make Himself heard over and above the noises from His counterpart' (Biko [1978] 1987:30). It is therefore one of the aims of black consciousness to give positivity to the general outlook of black people and the unique problems they are facing (Biko [1987] 1978:30-31). 
Related to this, Biko says that it is important for Christianity to get rid of the 'rotten foundation' created by whitedominateed theology and history writing. Biko ([1978] 1987:31) says: 'To this date black people find no message for them in the Bible simply because our ministers are still too busy with moral trivialities'. A theology which allows people to suffer and endure constant systemic oppression is no theology of hope. Biko ([1978] 1987:31) correctly argues: 'Obviously the only path open for us now is to redefine the message in the bible and to make it relevant to the struggling masses'. Black Theology should aim to remove spiritual poverty amongst black people and help people to see that the Christian God fights for them.?

In our day and age, we are at the fortunate place that decolonising of the curricula could be reflected upon. As a biblical scholar, the author of this article is concerned to approach the biblical text and the socio-historical context of the first century inspired by the concerns raised by black consciousness and decolonial thought, and which provide hopeful and life-giving theology which shows how black people can relate to Jesus in new ways. The following heuristic questions could be asked from the perspective of critical correlation between past and present experiences:

- In which ways were peasants in first century Palestine oppressed?

- In which ways did Jesus present the Kingdom of God as an alternative paradigm challenging an oppressive system?

- What are the implications of this when we critically correlate past and present experiences?

\section{Biblical analysis: Meeting the decolonial Jesus for the first time The first century as 'colonial' dominated space}

Van Eck (2009) was one of the first scholars to make us aware of the significant implication of seeing Jesus as an ethical-eschatological prophet and for illustrating how Jesus challenged the system's oppression of the poor. In his own insights, he was inter alia influenced by Borg (2006), Scott (2001) and others with whom he subsequently also critically engaged.

Borg (2006:81) convincingly argues that Jesus was active in an advanced pre-industrial agrarian context in which the Empire of Rome dominated and subjugated the local population. ${ }^{8}$ A small elitist and powerful class dominated the majority of the population and exploited them for labour. Politically speaking, these societies were fundamentally oppressive and dominated by the small elite which comprised of circa $2 \%-5 \%$ of the population. Economically speaking, this small elite group exploited the poor by claiming the majority of produce of agricultural production $(50 \%-65 \%)$. The ancient world had no middle class, but rather a binary

7.For a helpful discussion of "Self-Consciousness as Force and Reason of Revolution" and a discussion of black Theology see Turner (2008:69-82, especially pages 77).

8.It was the important work of Van Eck (2009) which first led me to Borg (2006) and others. setup consisting of a majority of people (circa 90\% - 95\%) in the lower class and the small elite in the highest class. Those who had wealth also had power, and vice versa. Those on the bottom of society had little power or wealth. Particularly interesting was that the rich adopted extreme forms of extravagant lifestyles (Borg 2006:83). This wealth was made possible by exploiting the labour of the poor and organising the system in such a way that wealth flowed directly to the controlling rich class. The rural, agricultural class consisted of peasants who were concentrated mostly outside of cities where the centre of production occurred. These peasants lived mostly at a basic subsistence level.

The world in which Jesus was born and in which he had his public ministry was essentially an imperially dominated system (Borg 2006:85-86). The Jews were conquered by Pompeii in $63 \mathrm{BC}$. They thus found themselves in a tributary domination system, which meant that they were ruled by local client rulers who extracted wealth from the poor by means of manual labour, so as to pay heavy taxes to the empire. To serve their ends, the Roman Empire would make use of the local elite to mediate on their behalf. The local elite were nothing less than instruments of imperial domination in their capacity as clients of Rome.

In the New Testament, we meet the family of Herod the Great, who was one such Roman client king of the Jews. It was his primary concern to serve Rome. Herod the Great had significant building projects which survive still today. These extravagant projects demanded significant funds, which were primarily gained by exploiting the working peasant class. Some of the buildings were built in honour of the emperor and this would directly challenge the very essence of Jewish faith and expectations. According to Borg (2006:88), these ambitious projects led to a further commercialisation of farming which demanded further exploitation of the poor working class. Ironically, many peasants lost their lands, as taxes were increased and lands were taken out of the hands of peasants who were downgraded from small-holding farmers to day workers. This world was characterised by increasing debt and a culture of fear and domination.

Shortly after Jesus was born, Herod the Great died (circa 4 $\mathrm{BCE}$ ), and a peasant revolt occurred that was effectively quashed by the Romans (Borg 2006:89). At that time, no fewer than 2000 people were crucified by the Romans as result of their rebellion. Herod the Great's kingdom was divided and his son Herod Antipas ruled Galilee where Jesus was active. Herod Antipas continued his father's building ambitions which implied further extraction of wealth.

In Jerusalem, an interesting change took place when Herod the Great's son, Archelaus was replaced by governors whom Rome themselves appointed, of which Pontius Pilate (26-36 AD) is the most well-known in the time of Jesus. The high priests, appointed by Rome, served as client rulers in service of Rome. The priestly class exploited the peasants and used the infrastructure in Jerusalem to exploit people 
TABLE 1: Parable of the Leaven

\begin{tabular}{|c|c|c|}
\hline Text & Original Greek or Coptic & Scott's (2001:21) translation \\
\hline Matthew 13:33 & 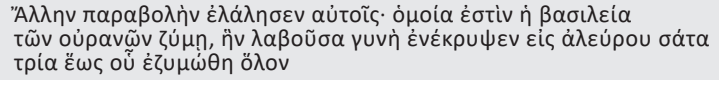 & $\begin{array}{l}\text { Heaven's imperial rule is like leaven that a woman took and concealed } \\
\text { in three measures of flour until it was all leavened. }\end{array}$ \\
\hline Luke 13:20-21 & 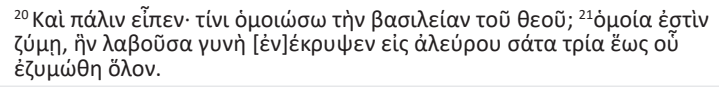 & $\begin{array}{l}\text { What does God's imperial rule remind me of? It is like leaven that a } \\
\text { woman took and concealed in three measures of flower until it was } \\
\text { leavened }\end{array}$ \\
\hline Thomas 96 & 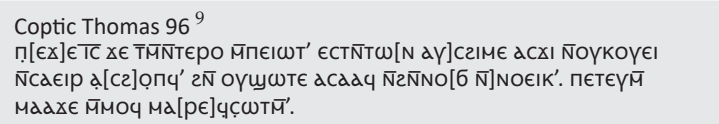 & $\begin{array}{l}\text { The Father's imperial rule is like [a] woman. She took little leaven, [hid] } \\
\text { it in dough, and made it into large loaves of bread. }\end{array}$ \\
\hline
\end{tabular}

and create their own wealth and power. Borg (2006:91) correctly points out that between 6 and $66 \mathrm{AD}$, a total of 18 high priests were appointed by Rome, mainly due to the fact that those who displeased Rome were replaced (see also Van Eck 2009). In Jesus' time, Caiaphas served as high priest for a particularly long time (18-36 AD). Borg (2006) sums it up well:

Thus, in Jesus' life, the high priest and temple authorities became mediators of imperial rule, responsible for collecting and paying tribute to Rome and for maintaining domestic order. Jerusalem and the temple, the sacred center of the Jewish world became the center of native collaboration with an imperial domination system. (p. 91)

When Jesus acted during his public ministry, and the period in which the New Testament material was produced, the context was dominated by exploitation of the peasants and a particularly sensitive context full of potential conflict during the interbellum periods (63 BC and 70 AD; cf. also 132 AD).

Jesus and his family belonged to the peasant class and Jesus is called a carpenter by Mark (Mk 6:3). Jesus grew up in Galilee in the period before his public ministry and would have been very aware of the major building projects of Herod Antipas in Sepphoris in which he would have been exposed to the exploitations of the poor by Rome and even more so by the hands of the Jewish leadership in Jerusalem (Van Eck 2009).

As a Jew, Jesus would have been shaped by what we call today the Old Testament. He would have been well-versed in the law and the prophets. According to Borg (2006:99), the macro-narrative of the Jews is one which accentuated their liberation from domination, as seen in the central importance of Moses and liberation from the oppression by the Egyptians and the promise to Abraham of a great nation with a land of their own. But the peasants and Jesus' daily experience was one in which their domination, dependence and exploitation constituted the dominant discourse. Not only does the Old Testament, both in the law and the prophets, directly speak against enslaving others, but also against the forms of debt and slavery which occurred during Jesus' time (see Lv 25:23). Amos, Hosea, Micah and Isaiah directly oppose the kind of domination and exploitation experienced in the time of Jesus and his first followers (Am 2:7; 4:1; 5:11; 6:4-6; Mi 3:1-2; Is 5:1, $7 ;$ Jr $7: 11){ }^{9}$
Van Eck (2009) correctly argues that Jesus could be seen as an ethical-eschatological social prophet who was critical of the utter exploitation of the people of his day and had a significant focus on the plight of the poor and marginalised.

In the following section we will illustrate by means of one of Jesus's parables that he was particularly revolutionary in challenging the system and placing the presence of the kingdom of God amongst the marginalised.

Scott (2001), in his book Re-Imagine the World, discusses the Parable of the Leaven, which we find in Matthew 13:33, Luke 13:20-21 and the Gospel of Thomas 96. He translates it as shown in Table 1.

Scott (2001) correctly points out that the Parable of the Leaven is considered even by critical scholars like the Jesus seminar as being original and close to what Jesus would actually have said. He also mentions that this parable contains a shocking metaphor. In the first place, one needs to understand the connotation of leaven as being a symbol of that which is unclean and is often used to express negative aspects (see also Van Eck 2009). In Mark 8:15, for instance, Jesus speaks negatively of the Leaven of the Pharisees and the Leaven of

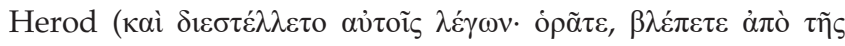

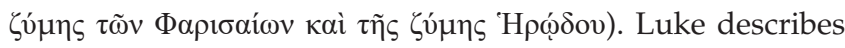
the Leaven of the Pharisees as being their hypocrisy

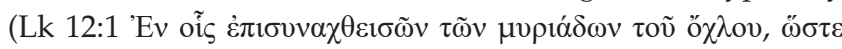

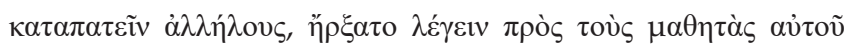

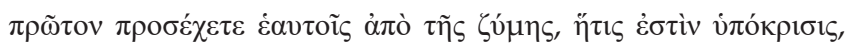

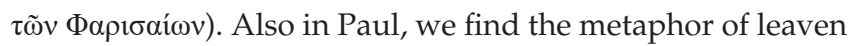
being used in a negative sense, as we see inter alia in 1 Corinthians 5:6 where Paul says that boasting is problematic and asks the Corinthians whether they do not realise that a

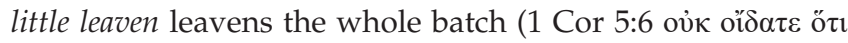

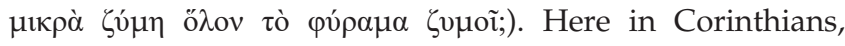
Paul explicitly associates the image of leaven with evil

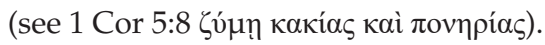

In the thoughts of Israel, leaven is generally associated with uncleanness (Ex 12:15-17) and unleavened bread with holiness and wholeness (Malina 2001:241). The reason, according to Scott (2001:27) is that leaven is associated with fermentation which in its turn is associated with the process of death and decay, and as such becomes a 'metaphor for corruption'. 
The shocking element of this parable is twofold as Van Eck (2009), following Scott (2001) points out. In the first place, the kingdom of God is associated with 'unclean' leaven. And secondly, the kingdom is associated with a rural woman. In ancient Mediterranean times, as we have discussed above, the peasantry was associated with those being exploited and on the margins of society. Furthermore, it was also a paternalistic world in which something as pertinent as explaining the presence of the kingdom of God would not in the first place have been described in terms of a peasant woman, and even less with the image of leaven. Here a peasant woman is used as the token emblem of the new kingdom of God (Van Eck 2009). This is a highly unusual and a rather counter-cultural image which would have surprised or most probably have shocked the first listeners. Thirdly, one needs to see the use of the word

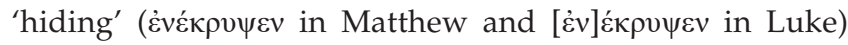
within the text describing the hiding or concealing act of the woman. The mentioning of three measures also represents a hyperbolic amount since it is enough to feed a 100 men (Scott 2001:28). Jesus contrasts the kingdom of God/Heaven with that of the Empire. Especially in the ancient context, an empire or kingdom was associated with power and wealth. But here, Jesus compares God's Kingdom with a weak, rural or peasant woman, and with leaven as an image which is normally associated with uncleanness or moral degradation. Thus, God's kingdom is present in the weak and vulnerable - present in unexpected spaces. However, the kingdom of God is presented as being concealed, but as leaven has the inherent potential to infiltrate the whole system.

Scott (2001:34) puts it well when he states: 'For all those who are leaven in their society, this parable assures them that the empire of God is like them', which in Jesus' time represented 'at least $80 \%$ of the population of first century Palestine who lived a subsistence existence'. God is the God of the poor and marginalised, depicted as being present especially in their midst. And like leaven, this empire has the potential to infiltrate and challenge the whole system. Jesus was par excellence a voice that challenged a system that believed that God's presence is found in the centre of the establishment and its power structures. However, Jesus is to be found in the margins, amongst those who are desolate and weak in the eyes of the controlling elite. In God's eyes, those who are 'out' are actually 'in'. This painted a new picture of worth. In God's eyes, the first shall be last and the last shall be first

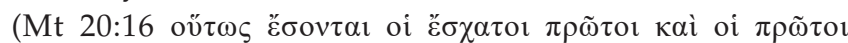
$\check{\varepsilon} \sigma \chi \alpha \tau 01)$. This is clearly an anti-establishment message and presents a Jesus who, as ethical-eschatological prophet, critiques the marginalisation and oppression of the system.

We also vividly see this truth in the parable of Lazarus and the rich man (Lk 16:19-31) (Van Eck 2009). Lazarus's existential position as an unclean beggar represents the zone of non-being, as he was seen as belonging to the socially outcast and expendables of ancient society. In the parable, the twist is clear in that heaven receives him with open arms, but rejects the rich man who had closed himself off from Lazarus's plight on earth and thus has to face the closing of heaven's gates to him in the life hereafter. The reader of the parable steps away from the parable knowing that God is especially close to the poor and that Jesus's parable shocks those who think that God is present with the controlling elite. In fact, Jesus directly confronts and challenges the status quo. Jesus was a true social-eschatological prophet and a revolutionary figure in his context (Van Eck 2009). From this perspective, we could argue that we meet in his parables a Jesus who we could reconcile with the notion of a 'decolonial spirituality'.

\section{Conclusion: Critical correlation between the past and the present}

Biko ([1978] 1987:30ff.) mentioned that black people do not associate with Christianity because they do not see the Bible speaking directly to their needs. When we meet Jesus in an ancient imperial or colonial space, we see how Jesus challenged the system of his day through his parables. We find in this Jesus hope for the struggle to empower our own people. As Biko ([1978] 1987:46) already said more than four decades ago, it is necessary to take seriously the movement of a people with 'a culture of defiance, selfassertion and group pride and solidarity... [A] culture that emanates from a situation of common experience of oppression'. Black consciousness seeks to 'infuse the black community with a new-found pride in themselves, their efforts, their value system, their culture, their religion and their outlook to life' (Biko [1978] 1987:49). It also seeks to transform the whole oppressive system and its values. Black Theology, says Biko ([1978] 1987:94), 'seeks to relate God and Christ once more to the black man and his daily problems'.

In theology, this can inter alia be done by reshaping the curricula of theological departments at universities in ways that we do not forget the legacies of people like Biko (see Maluleke 2008:124). In biblical studies, this might include reading Fanon and Biko as part of the prescribed literature and learning the skills involved in a critical correlation reading as we have done in this article. In this way, several results are achieved. Not only are students, from all cultural backgrounds sensitised to the works of Fanon and Biko, but also empowered with the critical frame and language to heuristically approach Scripture and build a bridge to their communities in the present. Such people will help others to rediscover Jesus as someone who was particularly concerned for the plight of the poor, the oppressed and the marginalised, and to appreciate voices like Fanon and Biko in a post-colonial context which poses ongoing challenges today. Rediscovering Jesus as a 
decolonial voice empowers Christ-followers in Africa to become agents of God's restoration and reconciliation, and find in Scripture a parallel to their own experience. Jesus's view of the kingdom of God in opposition to dominating and exploitative social structures inherently entails a more person-affirming view of the world. This will certainly appeal to black people who want to join Biko's dream of revitalising black consciousness. It also has implications for gender challenges in contemporary contexts (Maluleke 2008:128). In following Jesus' example, such people are also empowered to continue the struggle against colonial domination, oppression and exploitation. In a world of haves and have-nots, which was also the reality in Jesus' time, we clearly see Jesus standing on the side of the havenots. Jesus was a true revolutionary, and those who have a heart for black consciousness will find in this decolonised Jesus someone who stood up for the poor and marginalised, and showed that God is especially present with the downtrodden. Perhaps this view will also help us to see the depth and value of the Belhar confession in this regard, a confession providing an appropriate conclusion to this article.

\section{We believe:}

- 'that God has revealed himself as the one who wishes to bring about justice and true peace among people;

- that God, in a world full of injustice and enmity, is in a special way the God of the destitute, the poor and the wronged;

- that God calls the church to follow him in this, for God brings justice to the oppressed and gives bread to the hungry;

- that God frees the prisoner and restores sight to the blind;

- that God supports the downtrodden, protects the stranger, helps orphans and widows and blocks the path of the ungodly;

- that for God pure and undefiled religion is to visit the orphans and the widows in their suffering;

- that God wishes to teach the church to do what is good and to seek the right (Deut. 32:4; Luke 2:14; John 14:27; Eph. 2:14; Isa. 1:16-17; James 1:27; James 5:1-6; Luke 1:46-55; Luke 6:20-26; Luke 7:22; Luke 16:19-31; Ps. 146; Luke 4:16-19; Rom. 6:13-18; Amos 5);

- that the church must therefore stand by people in any form of suffering and need, which implies, among other things, that the church must witness against and strive against any form of injustice, so that justice may roll down like waters, and righteousness like an ever-flowing stream;

- that the church as the possession of God must stand where the Lord stands, namely against injustice and with the wronged; that in following Christ the church must witness against all the powerful and privileged who selfishly seek their own interests and thus control and harm others'. ${ }^{10}$ (this paragraph is a direct quotation of The Belhar Confession [1982:n.p.])

10.Viewed 17 May 2021 , from https://www.rca.org/about/theology/creeds-and confessions/the-belhar-confession/.

\section{Acknowledgements Competing interests}

The author declares that he has no financial or personal relationships that may have inappropriately influenced him in writing this article.

\section{Author's contributions}

J.K. is the sole author of this article.

\section{Ethical considerations}

This article followed all ethical standards for research without direct contact with human or animal subjects.

\section{Funding information}

J.K. is a National Research Foundation (NRF) B3-rated scholar and receives funding from the National Research Foundation and the University of Pretoria in his capacity as extraordinary professor.

\section{Data availability}

Data sharing is not applicable to this article as no new data were created or analysed in this study.

\section{Disclaimer}

The views and opinions expressed in this article are those of the author and do not necessarily reflect the official policy or position of any affiliated agency of the author.

\section{References}

Biko, S., [1978] 1987, I write what I like: A selection of his writings, in Aelred Stubbs C.R. (ed.), 15. Print, Heinemann, Oxford.

Borg, M.J., 2006, Jesus: Uncovering the life, teachings, and relevance of a religious revolutionary, HarperCollins, New York, NY.

Campt, T., 2004, Other Germans: Black Germans and the politics of race, gender, and memory in the Third Reich, University of Michigan, Ann Arbor, MI.

Du Bois, W.E.B., 1903, The souls of black folk, A.C. McClurg \& Co, Chicago, IL.

Dutch Reformed Mission Church (DRMC), 1982, The Belhar Confession, viewed 17 May 2021, from https://www.rca.org/about/theology/creeds-and-confessions/ the-belhar-confession/.

Fanon, F., 1952, Peau noire, masques blancs, Editions du Seuil, Paris.

Fanon, F., 1986, Black skin, white masks, transl. C. Lam Markmann, Pluto Press, London.

Gordon, L.R., 2000, Existentia Africana: Understanding Africana existential thought, Routledge, New York, NY.

Kok, J. \& Van den Heuvel, S.C., 2019, 'Preface', in J. Kok \& S.C. Van den Heuvel (eds.), Leading in a VUCA world, pp. v-xi, Springer Open, Cham.

Mabogo, P.B., 2008, 'Biko: Africana existentialist philosopher', A. in Mngxitama, A. Alexander \& N.C. Gibson (eds.), Biko lives! contesting the legacies of Steve Biko, 1 st edn., pp. 45-68, Palgrave Macmillan, New York, NY.

Malina, B.J., 2001, The New Testament world: Insights from cultural anthropology, 3rd edn., rev. expanded, Westminster John Knox Press, Louisville, KY.

Maluleke, T.S., 2008, 'Biko's challenge to religion', in A. Mngxitama, A. Alexander \& N.C. Gibson (eds.), Biko lives! contesting the legacies of Steve Biko, 1st edn. N.C. Gibson (eds.), Biko lives! contesting the leg.
pp. 115-128, Palgrave Macmillan, New York, NY.

Mbembe, A., 2021, Out of the dark night: Essays on decolonization, Columbia University Press, New York, NY.

Scott, B.B., 2001, Re-imagine the world: An introduction to the parables of Jesus, Polebridge Press, Santa Rosa, CA.

Turner, L., 2008, 'Self-consciousness as force and reason of revolution in the thought of Steve Biko', in A. Mngxitama, A. Alexander \& N.C. Gibson (eds.), pp. 69-82, Biko lives! contesting the legacies of Steve Biko, Palgrave Macmillan, New York, NY.

Van Eck, E., 2009, 'A prophet of old: Jesus the "public theologian"', HTS Teologiese Studies/ Theological Studies 66(1), Art. \#771, 10 pages. https://doi.org/10.4102/hts.v66i1.771 Woods, D., [1978] 1991, Biko, 3rd rev. edn., H. Holt, New York, NY. 